\title{
Sociabilidades e Valores: Um Olhar sobre a Família Árabe Muçulmana em São Paulo*
}

\author{
Oswaldo Truzzi
}

"O homem provê, a mulher constrói. Mil inimigos fora é melhor do que um em casa."

(Safadi e Basha, 1954)

\section{INTRODUÇÃO}

\begin{abstract}
A inda que a maioria dos descendentes de sírios e libaneses que imigraram para o Brasil seja constituída por cristãos - sobretudo católicos maronitas e ortodoxos-, a partir da década de 1950, surge no cenário paulistano uma nova leva migratória de árabes muçulmanos sunitas e xiitas -, já aqui presentes desde as primeiras décadas do século XX, mas até então muito pouco expressivos numericamente. Esse último movimento migratório é explicado pela conjuntura de depressão econômica que atingiu regiões mais atrasadas do Líbano após a Segunda Guerra Mundial (1939-1945). A falta de perspectivas para os jovens que residiam em regiões preponderantemente rurais, onde os conflitos político-religiosos eram mais presentes, impeliu os que ainda tinham
\end{abstract}

\footnotetext{
* Agradeço os valiosos comentários de Elza Berquó, Maria Filomena Gregori, Célia Sakurai e Ethel Kosminsky, colegas de percurso na pesquisa que gerou este artigo. Agradeço ainda a generosa acolhida de Charles Pessanha, editor da revista DADOS. As sugestões e críticas formuladas pelos pareceristas da revista em muito contribuíram para a melhoria deste artigo em sua versão final. Este estudo também se beneficiou de uma estadia de curta duração, financiada pela Fundação de Amparo à Pesquisa do Estado de São Paulo - FAPESP, na Universidade de Chicago, no início de 2006.

DADOS - Revista de Ciências Sociais, Rio de Janeiro, Vol. 51, n-0 1, 2008, pp. 37 a 74.
} 
alguma autonomia a decidir pela emigração. Hoje, muçulmanos, em sua maioria sunitas, respondem por contingentes apreciáveis de famílias libanesas, ainda que constituam um contingente numericamente muito menos importante que a imigração anterior de cristãos. Originários em sua maioria do vale do Bekaa ou de pequenas aldeias ao sul do país, concentraram-se em áreas da Região Metropolitana de São Paulo, como a região de Santo Amaro, na zona sul da capital, ou ainda a região do ABC paulista (Santo André, São Bernardo do Campo e São Caetano). Esse movimento migratório foi reforçado a partir de 1975, quando eclodiu a guerra civil libanesa (Osman, 1998; Gattaz, 2001). Hoje, a comunidade muçulmana no Brasil é estimada por suas lideranças como perfazendo entre meio e 1 milhão de indivíduos (Hayek, s.d.; Folha de S. Paulo, 23/9/2001; O Globo, 23/9/2001).

Ao contrário do que ocorre nos Estados Unidos ${ }^{1}$, onde a comunidade muçulmana provém, por assim dizer, de origens nacionais muito distintas, trazendo de cada origem traços culturais próprios, no Brasil, a esmagadora maioria dos muçulmanos é formada por famílias originárias do mundo árabe, especialmente do Líbano e, particularmente, do sul desse país. São possíveis, e existem, conversões de brasileiros não-descendentes de imigrantes muçulmanos, assim como muçulmanos originários de outros países, mas em contingentes numericamente pouco expressivos. Tais circunstâncias atuam como elemento de homogeneidade a fim de fazer coincidir as identidades étnica e religiosa no grupo. O próprio título da revista da comunidade muçulmana em São Paulo denuncia a origem comum: Al Urubat, O Arabismo.

Esses fluxos migratórios de muçulmanos libaneses em certa medida atualizaram as trajetórias sociais seguidas pelos antigos imigrantes: o começo como vendedores ambulantes de artigos populares e, em seguida, o estabelecimento de um comércio (Truzzi, 1992; 1997). A maior concentração ocorreu em São Paulo, onde os imigrantes, sempre aglutinados ao redor de mesquitas nas regiões de Santo Amaro, zona sul da capital, e do $\mathrm{ABC}$, dedicam-se hoje primordialmente à comercialização de móveis populares. Entre as famílias originárias do vale do Bekaa e do sul do Líbano, um grupo considerável de muçulmanos passou também a comercializar confecções (sobretudo em jeans), concentrados ao redor da rua Oriente, no bairro do Brás. Muitos desses imigrantes emigraram provisoriamente, fugindo dos combates de sua terra natal, alimentando inicialmente o sonho de retornar. Alguns voltam efetivamente para rever familiares ou a passeio, mas têm dificuldades em se 
estabelecer novamente no Líbano, em virtude das melhores perspectivas econômicas que o Brasil oferece (Osman, 2006). A imensa maioria estabeleceu-se no ramo comercial, mesmo que hoje mascatear seja pouco usual, em virtude da violência nas grandes cidades.

Este artigo tem por objetivo explorar as configurações e os valores familiares de árabes muçulmanos em São Paulo. No Brasil, os campos dos estudos étnicos e de família têm se desenvolvido segundo orientações razoavelmente paralelas. Assim, embora o estudo dos processos migratórios encontre, na caracterização das unidades familiares, um ponto de partida essencial, "esse material não tem feito eco junto ao campo preocupado em avaliar, no nosso país e, em particular, na cidade de São Paulo, os arranjos familiares, os padrões de conjugalidade e o mercado matrimonial, bem como o impacto das mudanças nas relações de parentesco em função dos novos agenciamentos de gênero e de geração" (Gregori, 2006:1).

Não obstante tal distanciamento, ressalte-se que, desde os anos 1980 do século passado, estudiosos vêm advogando a tese de que a família no Brasil não pode ser compreendida segundo traços homogêneos acomodados em um padrão singular que evoluiu da família patriarcal à família conjugal moderna, mas sim a partir de arranjos diferenciados, segundo especificidades de classe, gênero, idade e, acrescento eu, etnia e religião (Corrêa, 1994; Fukui, 1980; Fonseca, 1989; Durham, 1983; Sarti, 1996; Ardaillon, 1997; Figueira, 1987; Peixoto, Singly e Cicchelli, 2000; Heilborn, 2004).

Nesse último sentido, importa também analisar o grupo sob a ótica das confluências entre ethos religioso e ethos familiar. Tais ordens de relacionalidade primordiais - uma mais cosmológica, outra mais societária definem as condições básicas da presença desses indivíduos no mundo, aquelas que os sustentarão como elementos da vida pública e que pautarão suas condutas e seus desafios. Conforme observou Duarte, "qualquer iniciativa que tenda a influir na vida social contemporânea de modo a viabilizar sua adequação aos valores modernos por excelência [...] enfrenta a necessidade de indagar como se articulam família e religião, de que modo conformam representações e experiências de subjetividade mais ou menos sensíveis à pregação modernizante" (2006:8).

Para o presente estudo, foi realizada uma dezena de entrevistas em profundidade, envolvendo propositalmente indivíduos de religião 
muçulmana de diferentes faixas etárias (entre 20 e 66 anos), situações socioeconômicas (3 comerciantes, 2 líderes comunitários, 3 donas de casa e 2 estudantes universitários) e gêneros ( 5 mulheres e 5 homens). As entrevistas registradas (algumas gravadas, outras anotadas) duraram de 90 a 180 minutos e foram realizadas em locais de trabalho ( $3 \mathrm{em}$ escritórios junto a lojas, 1 em uma escola), residências (3), associações da comunidade (2) e café (1). Elas se constituíram na principal fonte primária de dados para o presente artigo, embora tenham sido também realizadas observações decorrentes de visitas a duas mesquitas, em uma das quais fui convidado para almoçar na respectiva sociedade beneficente. Embora fosse estranho ao grupo, fui bem recebido, despertando simpatias e certa curiosidade. Ali pude entrever o clima cultivado e os assuntos abordados entre famílias no almoço de sexta-feira, quando a comunidade normalmente se reúne. Além disso, procurei examinar, ainda que não exaustivamente, a bibliografia atinente ao tema das famílias muçulmanas no Brasil e nos Estados Unidos. No decorrer do texto, referências como L60m significam que o indivíduo L, de 60 anos, do sexo masculino, forneceu o depoimento citado.

\section{TRADIÇÕES E SOCIABILIDADES}

Entre famílias de origem cristã, os clubes representaram uma importante alternativa de socialização para a primeira geração nascida no Brasil (Truzzi, 1997). Entre muçulmanos, as sociedades beneficentes cumprem o papel de reunir e mobilizar a comunidade. Localizadas geralmente ao lado das mesquitas, constituem um espaço privilegiado de reunião para o almoço de sexta-feira, a organização de ações de benemerência e de ajuda mútua, e para que os jovens se conheçam e cultivem sua fé, em uma sociedade considerada, em geral, bastante permissiva pelas famílias de crença islâmica.

Se, para as famílias de origem árabe cristã, algumas já instaladas em São Paulo há cinco gerações, o grosso da vida social já se secularizou, o mesmo não ocorre com as famílias muçulmanas. Além de a imigração ter ocorrido há menos tempo e, portanto, os costumes e as tradições da terra natal se mostrarem mais presentes, a experiência religiosa particular e diferenciada do restante da sociedade, nesse caso, é muito mais estruturante da conduta do grupo quando comparada à de sírios e libaneses de origem cristã. Nesse sentido, graças ao estranhamento comum diante da sociedade mais abrangente, a experiência de grupo minoritário religioso aproxima os muçulmanos da experiência outrora 
vivenciada pelos primeiros grupos de judeus em São Paulo, guardando, desse ponto de vista, relativa semelhança, não obviamente quanto às práticas religiosas, mas quanto à singularidade da experiência de inserção em um contexto de catolicismo hegemônico.

Sendo a imigração mais recente, entre os entrevistados, muitos ainda desfrutam (ou desfrutaram até pouco tempo) do convívio com pais, familiares ou amigos imigrantes. Os vínculos mantidos com a terra de origem, em função da maior facilidade de deslocamento (menor custo e menor tempo), conferiram à empreitada migratória, outrora longa e custosa, um caráter transnacional (Schiller et alii, 1995). Tal situação impõe, na maior parte das vezes, o domínio da língua árabe no cotidiano familiar. Como relatou um dos entrevistados, tão resoluto em sua fé quanto em outros assuntos, as coisas são muito claras: "português é na escola, em casa é árabe e na loja é misturado" (L60m). O árabe foi aprendido no convívio familiar, pois a maior parte dos entrevistados não freqüentou escolas da colônia. Mesmo assim, de uma geração para outra, a fluência e mesmo a capacidade de comunicação vão diminuindo, pois a sobrevivência do árabe como língua praticada no seio das famílias depende em boa medida da presença de imigrantes na própria família e da densidade dos vínculos mantidos com a terra de origem.

Outra esfera do cotidiano em que o peso da tradição familiar se mostra presente é obviamente a alimentação. De fato, os entrevistados foram unânimes em apontar a comida árabe como um referencial importante, ainda que longe de se mostrar absoluto, já que o insinuante arroz com feijão (este muitas vezes substituído pela lentilha) acaba aos poucos constituindo a base das refeições em muitos lares. Naqueles que contam com mulheres imigrantes, o vigor da comida árabe é normalmente mais presente. É perceptível a valorização, não da comida árabe de modo geral, abstratamente falando, mas, sobretudo, daquela preparada em casa, conforme os costumes herdados, distinguindo-se assim da culinária árabe tipicamente comercial. No fundo, a comida valorizada está intimamente associada a seu preparo, que, por sua vez, está associado à condição feminina.

A alimentação compreendida nesses termos e a comunicação em árabe - ao menos entre os mais idosos - reforçam assim uma sociabilidade própria, endógena às famílias muçulmanas em São Paulo. Pode-se dizer que ela se assenta sobre pelo menos três níveis: em primeiro lugar, nas relações no interior da própria família, em seguida, no grupo de fa- 
mílias originárias da mesma aldeia, cidade ou região, já que laços de conterraneidade constituem uma referência importante para o grupo, e, por último, na comunidade islâmica mais ampla. Nesse último sentido, é importante frisar a concepção de que ser muçulmano é pertencer a um tipo de família universal, compartilhar de uma unidade que depende de cooperações mútuas. Isso nos conduz ao tema das esferas de sociabilidade prevalecentes tanto no trabalho quanto nas poucas horas de lazer disponíveis.

O relacionamento com membros de fora da comunidade islâmica é marcado, sobretudo, pelos contatos exigidos pelos negócios na esfera dos relacionamentos comerciais, tanto entre empresas quanto no interior da própria firma, quando esta adquire certo porte e exige o recrutamento de funcionários além do trabalho familiar. Nesse caso, é comum a convivência com moças de famílias nordestinas, bastante abundantes tanto no Brás quanto em Santo Amaro, empregadas como atendentes de lojas.

Como a concorrência é grande, trabalha-se muito na colônia de modo geral, em períodos que muitas vezes extrapolam o horário dito comercial. A maioria dos comerciantes só tem livre o domingo, quando a família ampliada se reúne para almoçar, normalmente na casa do chefe (patriarca) da família ou de seu filho mais velho, vez ou outra recebendo algum convidado. Há também os eventos da comunidade, que geralmente ocorrem junto às mesquitas: casamentos, festas etc. A freqüência ao clube da colônia, localizado no bairro do Riacho Grande, zona sul de São Paulo, foi apontada por muitos como bastante episódica.

Sendo assim, a sociabilidade dos indivíduos é quase que exclusivamente dependente do círculo familiar e das relações da família com a colônia muçulmana, pois, como observou um entrevistado, "trabalha-se fundamentalmente em família" (Q28m). Fora da família não há nada muito além das atividades propostas pelas mesquitas e respectivas sociedades beneficentes associadas a cada uma delas. Isso se reflete mesmo em termos espaciais, pois se observa que as famílias procuram se aglutinar próximas tanto do trabalho (em geral, da loja) quanto da mesquita que freqüentam. Há uma expectativa implícita de que os membros de uma família permaneçam o máximo possível juntos, seja em casa, no trabalho, seja em outras atividades. Espera-se assim manter as crianças sempre envolvidas no seio da família, a fim de que se lhes possa transmitir os valores da vida familiar em um ambiente islâ- 
mico. Esse aspecto também pode gerar incompreensões junto a estratos sociais não-muçulmanos que valorizam cada vez mais a privacidade individual. É significativo, por exemplo, que, dos indivíduos entrevistados, cinco tenham sido acompanhados por familiares ${ }^{2}$. Mais que isso, por familiares do mesmo sexo do(a) entrevistado(a), já que papéis muito contrastantes segundo o gênero parecem conformar também sociabilidades distintas de acordo com o gênero.

No âmbito das sociedades beneficentes, cujas sedes são normalmente construídas em áreas anexas às mesquitas, ocorre um conjunto expressivo de atividades sociais, culturais e de apoio à comunidade. Elkholy refere-se à importância das mesquitas para as comunidades muçulmanas americanas nos seguintes termos: "A instituição da mesquita desempenha um papel crucial à vida de toda a comunidade, já que nela as funções psicológicas vitais da religião integram a personalidade do indivíduo à da sociedade em seu entorno" (1966:134, tradução do autor). No Brasil, ali é o lugar no qual a comunidade se reconhece, onde as informações circulam, as pessoas se encontram, as relações são revigoradas, os matrimônios tecidos, as visitas de autoridades recebidas, as comemorações celebradas, os negócios discutidos etc. O almoço de sexta-feira, que ocorre após os serviços na mesquita, é, semanalmente, o momento mais importante de reunião social da comunidade.

Os mecanismos de entreajuda, por exemplo, são favorecidos por uma espécie de dízimo (mas que, na verdade - explicou-me um entrevistado -, corresponde a $2,5 \%$ do que se ganha), preconizado pela doutrina islâmica, o zakat ${ }^{3}$, encaminhado à sociedade beneficente ou diretamente aos pobres. "Às vezes a gente empresta, mas na verdade dá, porque quem recebe não precisa devolver, porque nossa religião exige essa parcela de doação" (L60m). Em outras ocasiões, cada vez mais raras, os empréstimos são realizados na base da confiança, avalizados pela rede de relações da colônia.

Aqueles habituados a laços pessoais de confiança, reciprocidade, generosidade, hospitalidade, compromisso etc. acabam estranhando uma ordem social cada vez mais individualista e impessoal. "Hoje as coisas estão ficando mais difíceis, os problemas de São Paulo, o jeito de viver em São Paulo está cortando muito essa relação entre as pessoas. As relações com os seres humanos estão deixando você com o coração duro, entendeu?" (N52m). 
Entre os muçulmanos entrevistados, em qualquer faixa etária, impressiona assim a circunstância de a sociabilidade das famílias estar ancorada em boa medida na vida sociorreligiosa da comunidade, em um padrão muito distinto dos árabes cristãos, entre os quais é relativamente comum encontrar famílias que não colocam o pé em uma igreja há meses. Para os muçulmanos, a religião parece revelar-se assim muito mais presente. Além disso, parece estruturar mais o cotidiano vivido. Segundo Hayek (s.d.), "os cinco pilares do Islã são a estrutura de vida dos muçulmanos": a fé (chahada $\left.a^{4}\right)$, a oração $\left(\right.$ salat $\left.^{5}\right)$, o interesse pelo necessitado (zakat), a autopurificação pelo jejum ${ }^{6}$ e a peregrinação anual à Meca (hajj), para quem tiver posses para tal".

Inúmeras vezes, em meio às entrevistas, foram feitas alusões aos preceitos do islamismo para justificar atitudes, comportamentos e juízos de valor. A própria brochura impressa sob os auspícios da Assembléia Mundial da Juventude Islâmica, destinada a apresentar o Islã e os muçulmanos, reconhece que ambos podem parecer exóticos ou mesmo extremistas no mundo moderno. Explica, contudo, que

talvez isso aconteça porque a religião não domina a vida do dia-a-dia no Ocidente de hoje, enquanto os muçulmanos têm a religião sempre presente em suas mentes e não fazem distinção entre o secular e o sagrado. Acreditam que a Lei Divina, chari'a, deve ser tomada seriamente. Por isso, assuntos relacionados com a religião continuam tão importantes (Hayek, s.d.).

Desse modo, a religião tem, para os muçulmanos, uma influência ao mesmo tempo profunda e abrangente sobre suas atitudes e condutas. Para os muçulmanos, todos os atos necessários à vida humana encerram um sentido e um significado religioso, contido na chari' $a$, conjunto de preceitos religiosos islâmicos. A chari'a estabelece regras para as práticas religiosas, para as famílias e os casamentos, para a conduta e interação social, para a ingestão de alimentos e para o próprio asseio pessoal ${ }^{7}$.

"Religião é uma coisa que prende a pessoa. Fé é igual a um termômetro: quando é baixa, a pessoa faz coisa errada", disse-me L60m, que se desculpou por ter de interromper a entrevista por meia hora para rezar, junto com seus três filhos, todos eles ajoelhados, realizando abluções e voltados para Meca. Explicou-me depois que diariamente vai à mesquita às 5 horas da manhã e, por me julgar incrédulo, desafiou-me a 
permanecer apenas três dias com ele, ao cabo dos quais eu estaria convertido ao islamismo.

A busca pela observância de preceitos religiosos na vida diária não parece ser característica exclusiva, entre os entrevistados, das gerações mais idosas. R20m, por exemplo, afirma que sua vida social, mesmo freqüentando uma universidade, é condicionada pela religião: não bebe álcool, não come carne de porco ${ }^{8}$, pratica o ramadã todo ano e, no mínimo, às sextas-feiras freqüenta a mesquita. "É Deus quem faz cair uma folha", observa, explicando-me Sua onipresença. Critica o descuido com a educação religiosa que recebeu de seus pais, ligados mais a "preocupações materiais", e conta que se reaproximou da religião há cerca de seis anos, na adolescência. Aí começou a se questionar e sentiu a necessidade de afinar sua prática com o discurso religioso.

Diretora do Centro da Juventude Islâmica e formada em Ciências Sociais pela Universidade de São Paulo - USP, S27f apresenta uma história similar. Ela diz que teve uma educação na qual seus pais "passaram a cultura, a língua, nossos costumes, a tradição enquanto árabes, não enquanto religião islâmica. A religião foi uma busca pessoal".

Feitas essas primeiras observações quanto ao uso mais comum da língua natal, quanto ao cultivo de uma tradição alimentar própria, à vivência religiosa relativamente mais intensa e quanto ao caráter da sociabilidade das famílias na colônia, marcado fundamentalmente pelo trabalho e pela freqüência às sociedades beneficentes, é conveniente aproximarmo-nos do elemento mais essencial para compreender as configurações familiares entre as famílias muçulmanas, hoje, em São Paulo.

\section{UMA CULTURA PATRIARCAL}

Na literatura socioantropológica brasileira, unidades patriarcais - clãs formados por parentelas legítima e ilegítima em grandes estabelecimentos rurais - como modelo de formação da família brasileira encontram sua maior expressão em Gilberto Freyre (1933). Segundo Antonio Candido (1951), tal padrão original teria perdido sua vigência em decorrência dos processos de urbanização e de industrialização, emergindo daí o modelo de família conjugal moderna. Corrêa, em artigo originalmente publicado no início dos anos 1980, criticou a fixidez de ambos os modelos, alertando para "a ilusão de que o estudo da forma de organização familiar [...] de um grupo dominante numa determina- 
da época e lugar possa substituir-se à história das formas de organização familiar da sociedade brasileira" (1994:19), sugerindo assim "a existência de um panorama mais rico, a coexistência, dentro do mesmo espaço social, de várias formas de organização familiar" (ibidem:37).

Seria por demais ingênuo advogar aqui uma aderência do modelo patriarcal, tal qual descrito por Freyre, aos árabes muçulmanos instalados hoje em São Paulo, ainda que esse autor tenha destacado a presença, não esporádica, porém farta, de descendentes de moçárabes entre os povoadores e primeiros colonizadores do Brasil, através dos quais tantos traços de cultura moura e mourisca se transmitiram (Freyre, 1933:286-320). No entanto, tratando-se sobretudo de famílias de imigração relativamente recente, que se inseriram em contextos urbanos, como o da metrópole paulistana, como comerciantes de classe média, a família árabe muçulmana guarda mais semelhanças com o modelo patriarcal no tocante a valores do que em relação à sua constituição propriamente dita (no sentido, entre outros exemplos, de incorporar parentelas ilegítimas).

De fato, trata-se então de ressaltar o caráter eminentemente patriarcal dos valores presentes na tradição familiar, expresso em múltiplas manifestações, algumas das quais explorarei aqui. Essa característica importante, herdada da tradição familiar, atribui papéis muito diferenciados ao homem e à mulher.

O homem é entendido como o responsável pela sobrevivência econômica, pelo destino e encaminhamento dos filhos, pelos assuntos de natureza social ou política. É a pessoa que decide em última instância, em se tratando de assuntos externos ao lar. Justifica-se esse papel graças à sua maior experiência e exposição à vida pública. Isso não exclui a possibilidade de consultas e de discussão com a esposa, mas a autoridade e a responsabilidade final sobre os destinos familiares recaem sobre ele, concebido como aquele que tem experiência, conhecimento e autoridade em seu papel. É o provedor, sua honra e seu orgulho próprio derivam de ele saber cuidar de sua família. Desse modo, é para ele uma vergonha admitir alguma necessidade.

Os filhos, sobretudo os homens, são entendidos como responsáveis pela continuação da família e normalmente observam uma grande, se não absoluta, obediência aos pais. 
Quando vou me referir a ela, é Dona A; quando vou me referir ao meu pai, é Senhor B, sempre é senhor, senhora, ou dona. Mesmo em árabe. Em árabe, nós temos uma maneira de focar um respeito: sempre é chamar a mãe e o pai pelo nome do filho homem mais velho, por exemplo, meu irmão mais velho, por isso eu te falei, a seqüência da geração é o homem, o nome do meu irmão é $X$, então, meu pai é chamado por respeito de 'Abu-X' ('Pai de $X^{\prime}$ ) e a mãe, 'Um-X' ('mãe de X'), então é um respeito. A referência é o filho mais velho. Entendeu? Se você fosse um patrício, eu os apresentava por esse nome (P46f).

A nítida preferência por filhos homens associa-se à circunstância de eles representarem a continuação da família, do sobrenome, admite P46f, com certo pesar: "existe, não vou mentir, existe". Isso ocorre porque, quando a filha casa, ela muda de família, passa a pertencer à família de seu marido. Os filhos gerados também "pertencem" ao marido (e não à mãe, como notaremos oportunamente), em uma concepção francamente patrilinear.

Por outro lado, de forma geral, o papel da mulher é o de procriar e educar os filhos. Poderíamos acrescentar: para o homem. O casamento é o meio pelo qual a mulher se transforma em um ser estável e socialmente maduro. A maternidade completa a obra, tida como valor muito importante, chegando mesmo a justificar, em alguns casos, o abandono da esposa, caso esta seja incapaz de gerar filhos. Assim, mulheres solteiras e sem filhos são freqüentemente marginalizadas socialmente (Bowen e Early, 1993:77). "Homem quer filho, não ter é problema" (L60m). Nesse mesmo sentido, o celibato do homem é encarado de forma negativa. O bom encaminhamento dos filhos e das filhas pressupõe assim o casamento desses.

O problema complica-se e toma uma dimensão mais aguda porque a religião islâmica não prevê a adoção de filhos, tal como no mundo ocidental. Vejamos dois relatos:

Nossa religião não permite adoção, por quê? Porque você não sabe quem você está adotando, pode ser que você esteja adotando uma criança que mais tarde vai gostar da própria irmã sem eles saberem, então, nos países árabes não é permitida a adoção; é permitido, sim, você criar e educar uma criança, mas você tem que saber a origem e a raça, de onde ela veio, a procedência dela, se ela tem irmão ou não tem. Ela vai continuar a ter a família dela, a origem dela é a mesma, ela não pode mudar 
[...] (P46f). [L60m é peremptório:] não pode adotar, pode criar. Pai é de sangue.

Uma vez que constituir família e ter uma prole numerosa, contribuindo assim para o incremento do número de fiéis, constitui um valor tradicional da comunidade, o aborto é interditado, a menos nos casos em que a mãe corra um real risco de vida. Já o controle da natalidade é sujeito a uma apreciação mais ambígua. Em geral, métodos contraceptivos são tolerados, desde que não sejam permanentes, como, por exemplo, a ligação de trompas.

No que tange à questão da homossexualidade, do ponto de vista da comunidade, o problema não existe porque, na hipótese pouco provável de algum caso ocorrer, a pessoa é simplesmente banida pela comunidade. M57f e L60m afirmam que não conhecem nenhum caso. "Se existir, a comunidade isola, o cara se mata, se joga de cima da montanha" (L60m). N52m informa que "a pessoa é rejeitada e, se possível, vai ser banida. A pessoa é tida como desconhecida, ela não tem espaço. Não tem liberdade, ela necessita de ter limite".

Ainda que o homem seja o responsável, em última análise, pela família, a mulher domina o cotidiano familiar, sobretudo no que se refere à criação dos filhos até uma determinada idade. "A prioridade da mulher é cuidar dos filhos" (R20m). "Quem é a pessoa mais próxima? Três vezes a mãe e depois o pai. Está no Alcorão" (L60m).

Tendo por obrigação primeira educar os filhos, as oportunidades de profissionalização para a mulher muçulmana são, ainda hoje, encaradas com muito receio, ainda que seja crescente a inserção delas no mercado de trabalho. "A maior parte, hoje, trabalha. Nós temos algumas executivas muito bem-sucedidas, mulheres que conquistaram [...], médicas, eu tenho uma na família que é promotora do Estado de São Paulo" (P46f). Ao longo das entrevistas, tornaram-se claras, no entanto, as inúmeras resistências, advindas não apenas em decorrência da obrigação de educar os filhos mas também de não se expor diante dos homens fora do círculo familiar. "Quanto à mulher ser educada, freqüentar escolas, tudo bem. Mas, no trabalho, o ambiente importa. De preferência dentro de casa. Se for um trabalho, por exemplo, em que um homem e a mulher ficam sós, não pode" (R20m). L60m explica que, em primeiro lugar, a mulher deve cuidar do lar, incluindo aí a educação dos filhos; depois, se necessário, ela pode trabalhar no negócio da família; por úl- 
timo, torna-se muito mais complicado "se trabalha misturado, se tem contato com outros homens".

É provável que as resistências à profissionalização feminina encontrem-se, portanto, vinculadas ao mesmo tempo às obrigações domésticas, ao desejo de "resguardá-la" dos outros homens e também associadas a uma compreensão arraigada do homem como provedor. Ao se profissionalizar a mulher, essa concepção subverte-se, e é provável que, em muitos casos, o homem se sinta ameaçado, envergonhado ${ }^{9}$. De modo geral, pode-se afirmar que, quanto mais conservadora a família e quanto menor o tempo no Brasil, maiores as resistências à mulher se profissionalizar fora do ambiente familiar, a menos em casos de necessidades econômicas incontornáveis. O mesmo se aplica aos trajes. Em conexão com a questão da profissionalização feminina, vale a pena explorar a noção de resguardo feminino, pois é ela que justifica o uso de vestimentas características, entre as quais o hijab (véu).

Doutrinariamente, no islamismo, a mulher, quando em público, deve cobrir todas as partes do corpo para resguardar-se. Toda a sensualidade, disse-me um entrevistado, deve ser assim guardada para o marido, para dentro de casa. No islamismo, explicou-me Q28m, "a mulher é bastante respeitada, é como um tesouro, uma pedra preciosa, precisa ser guardada. Se você tiver um grande diamante, vai querer ficar mostrando, expondo a todo mundo? Vão querer tocá-lo. [...]. Então o resguardo, a vestimenta, as maneiras são decorrência desse grande valor da mulher". N52m compartilha da tese:

É claro, a mulher tem que ser reservada. Ela tem que estar arrumada na casa dela, pra família dela, você entende isso? E aqui é o contrário, quando ela se arruma, ela vai pra fora, e quando tá dentro de casa, tá uma desgraça. Depois ela fala, por que o cara vai ter uma amante aqui e amante ali? Porque a senhora tava lá bem arrumada e aqui tá a maior tristeza. Então o cara acaba rejeitando a própria mulher dele. [...]. Na colônia, tem separação, mas é menos. Porque lá, a maioria, claro, reserva mais a família. Dá mais valor à família.

Entrevistada, M57f reconhece que boa parte da colônia acha "que eu deveria usar véu, como presidente da Liga das Senhoras Muçulmanas. Mas aprenderam a ver mais os meus atos, concluindo que sou mais muçulmana de coração. Nos costumes, o importante é sentir o que quer, fazer tudo pela vontade própria". P46f também não usa véu e encara isso como uma prerrogativa própria, fruto da adaptação a uma so- 
ciedade ocidentalizada. Quando vai ao Líbano, ela passa a usá-lo. Indagada se, como presidente da sociedade, era cobrada por não usá-lo aqui no Brasil, disse-me que não,

[...] porque a entidade é mais aberta. É bem mais aberta. Os fundadores, desde a fundação em 1929, são de pessoas que se adaptaram a São Paulo, vamos chamar assim, ao local onde eles viviam, mas de não abandonar a religião, de tentar trazer a comunidade para a religião, para a mesquita. Então, eu acho que a cobrança disso não existe muito não. Porque isso daí é de mulher para Deus, porque eu sei minha obrigação, com eu tenho outras várias obrigações que eu tento mantê-las e que essa daqui, realmente, ela está em falta, né? Mas isso é de cada mulher (P46f).

É possível também se observar, tal como relataram Haddad e Smith (1996) referindo-se ao caso americano, um duplo padrão de vestimenta para mulheres muçulmanas mais aculturadas, dependendo do local onde estejam: na mesquita, na própria casa, no trabalho ou simplesmente nas ruas. Todavia, essas são prerrogativas, ambigüidades e, em certo sentido, dilemas de uma geração já nascida no Brasil, que exerce um papel importante na transição entre a velha e a nova cultura, freqüentemente sendo vítima de ambas. Conforme admitiu P46f, "eu acho que nossa primeira geração sempre foi a mais difícil, porque ela tem que lidar, de um lado, com a cultura do país onde ela vive, do lugar onde ela vive, de outro, com tudo o que vem da tradição". Nesse sentido, ao menos teoricamente, a geração dos netos dos imigrantes provavelmente enfrentará obstáculos menores no que diz respeito a uma identidade desintegrada entre os valores étnico-religiosos do grupo e os da sociedade mais abrangente.

No tocante à castidade, embora supostamente o casamento constitua, na doutrina islâmica, uma precondição às relações sexuais para ambos os sexos (Dahl, 1997), sua observância é muito mais cobrada para as mulheres. N52m explica:

Ele [Deus] colocou ela [a virgindade] pra ser preservada. Não consigo entender, tá tudo ficando complicado no mundo, tudo pode, tudo pode. Lá vai produzir um ser humano. Se a gente tem uma fábrica que vai lançar um carro, fica segredo guardado no cofre, 1.000 quilos com uma porta, agora em 'porta' de ser humano, todo mundo pode entrar e sair. Em porta de Volkswagen, ele é trancado e só é dado pra pessoas de confiança. Pra ninguém roubar projeto de carro que vai ser feito amanhã. E veja bem, tudo tá errado, o cavalo, se ele não tem documento, não 
sabe quem é pai dele, mãe dele, ele não tem mais valor. E o homem, hoje? Não tem mais origem.

Questionado sobre se o mesmo valia para os homens, ele observa que "Deus não colocou nele a virgindade", isto é, a "prova" de que não é mais virgem, após o ato sexual. Contudo, explica por que também se justifica a castidade no homem, sob seu ponto de vista:

\begin{abstract}
Será que todas as mulheres têm todas as qualidades boas? Não. As qualidades boas de uma mulher não se encontram todas em uma só. Então ele sai com uma mulher e depois com outra e com outra, cada uma tem uma qualidade. E pra ele ficar com uma, não consegue mais, porque ele conhece dez mulheres e cada uma tem uma qualidade, no relacionamento. Então ele não consegue ficar com uma só. E começa aquele mal-estar familiar. Agora, quando ele conhece só ela e ela só ele, a relação dura muito mais. Começa a não existir a preferência. Agora quando você experimentou dez, o casamento [...]" (N52m).
\end{abstract}

Na prática, é provável que muito mais homens do que mulheres transgridam a doutrina islâmica nesse ponto. L60m afirmou ser a virgindade muito importante, "para não comprar gato por lebre". Conhece casos em que a noiva foi rejeitada porque o noivo desconfiava de sua virgindade, conduta com a qual está de acordo: "Se o marido fica quieto, quando acontece a primeira briga do casal, ele joga na cara da mulher que ela não casou virgem". Indagados em separado, seus filhos, na faixa dos 20 anos, logo observam que a perda da castidade antes do casamento é mais complicada para a mulher, pois, no homem, "ninguém fica sabendo". L60m observa também que a castidade entre homens depende da fé. R20m, aparentemente empenhado em seguir a doutrina nesse ponto, apesar de seus fogosos 20 anos, comentou ser a vida terrena uma prisão, ao ser inquirido sobre o tema.

Indagado sobre como a colônia trata a questão de filhos fora do casamento, N52m explica que "aceitam melhor do que se ficar fora. Rejeitam num primeiro momento, mas depois que nasceu, eles vão buscar, em $99 \%$ dos casos ele é querido. Eles fazem questão de trazer o filho pra dentro da casa, fazem tudo pra cuidar dele desde pequeno, junto com os outros filhos. Não tem como". Faz, entretanto, uma ressalva reveladora: "Isso tudo quando têm a chance, porque às vezes a menina some". Provavelmente para não envergonhar a família, pois o status familiar e, em particular, o de seu chefe, não raro se relaciona à habilida- 
de de controlar a sexualidade das mulheres da família (Mernissi, 1975:161; Donnan, 1988:99).

\section{Dote}

A instituição do dote no casamento é outro aspecto revelador dos papéis diferenciados atribuídos ao homem e à mulher, e que também se relaciona à questão da perda da virgindade. M57f observa que "o islamismo dá mais direitos à mulher. Para protegê-la, Deus deu o dote". N52m entende ser o dote obrigatório, pois "serve para reprimir. Mulher precisa ter garantia, porque homem tirou a virgindade dela. O que machuca o homem é o dinheiro. Tem um valor simbólico. Dinheiro não materializado, mas escrito. Hoje com dólar (moeda estável), antes camelo, carneiro. Quando o homem tem moral, paga. Se não, quatro ou cinco pessoas vão pressionar".

P46f explica:

[...] a nossa religião, o islamismo, eu acho que, nessa questão do casamento, ele é perfeito, porque ele dá todas as condições e garantias da mulher caso o homem venha a abandoná-la, tenha outro problema. O dote seria uma garantia para a mulher no futuro [...]. Por quê? Porque ela casou. No próximo casamento, é mais difícil. Fica mais difícil. Hoje existem casamentos rompidos e voltam a se casar normalmente. Hoje mudou muito a visão nessa parte. Mas esse dote seria exatamente isso, ela ter uma garantia, ela poder tá sobrevivendo, até arrumar um trabalho ou até ela virar [...], resolver a vida dela.

O dote funciona como uma espécie de seguro para a mulher, caso seu casamento não sobreviva. Ele pode ser simbólico no sentido de ela não receber nada na hora do casamento, mas ele é estipulado e, se necessário, mais tarde será cobrado pelo xeique e por outros da comunidade. L60m lembra que "mulher fala que perdoa (o valor do dote), mas na briga cobra". Assim, se o homem for "honrado" e desejar manter uma boa imagem na comunidade, ele necessariamente paga o dote. O dote também é pago pelos filhos à mãe, quando esta se torna viúva, "para que ela possa se casar de novo" (L60m).

Desse ponto de vista, representa certo capital para que a mulher possa começar uma nova vida. Por que uma nova vida? Porque, como a cultura é patriarcal, se ela quiser se casar de novo, ela vai se agregar a outra família, a de seu novo marido. A unidade familiar é, assim, definida 
pelo homem. Isso explica seus privilégios no sistema de herança. "Pra casa do homem é, por exemplo, duas vezes para o homem e uma para a mulher" (P46f). "É dividido, a mulher normalmente leva um terço. Por exemplo, o casal que tem uma filha e um filho. Pela religião, o filho leva dois terços e a filha um terço" (N52m). "Homem dois terços, mulher um terço. Mas o homem cuida dos pais e irmãs em caso de necessidade" (M57f). Assim, o homem leva mais sob a justificativa de que tem mais responsabilidades, precisará cuidar de toda a família: dos pais idosos, dos irmãos e das irmãs, além de sua própria família, compreendendo aí esposa e filhos:

O filho tem por obrigação amparar os pais e a mulher dele; a mulher dele tem que ser amparada por ele também. Ele tem que ter condição de sustentar ela, então ele, no caso dos pais ficarem doentes, [...] pela lógica, eles têm que ficar com o filho homem. Ou aquele que preferirem, mas a lógica manda ficar com o filho homem. O primogênito ou qualquer um. Aí vai onde for mais espaçoso, onde o pai se sente melhor. Acaba ficando onde ele se dá bem com a nora (N52m). [Indagado se o irmão tem responsabilidade sobre suas irmãs, N52m não titubeia:] Claro, se ela está em casa, ele tem toda responsabilidade de cuidar dela, enquanto ela está em casa [isto é, enquanto ela não casar]. Dar proteção, até casar, mesmo depois de casada, se ela for separada, ele tem obrigação de dar proteção, acolher. A mulher sempre tem que ter proteção de família. A natureza não fez ela que nem o homem, uns falam que fez, mas não fez. Ela tem uma estrutura, um físico e ele tem outro. É mais fácil falar que é tudo igual, mas tem limite pra falar que é tudo igual. É mais fácil falar que é tudo igual do que diferenciar.

L60m afirma claramente que "mulher não pode dormir sozinha: a viúva vai morar com o filho ou o filho vem morar com ela". R20m declara que "normalmente o filho mais velho assume os pais viúvos"; e acrescenta, indignado com "Dia dos Pais, Dia das Mães: todo dia é dia deles. Isso é falta de conhecimento da religião".

As entrevistas sugerem que, entre estratos mais altos, o tema é mais sujeito a controvérsias. M57f, após observar que sua mãe viúva continuou a morar sozinha, em sua casa, afirma que a sociedade de senhoras (de elite, beneméritas) que preside tem, entre seus planos, "batalhar por um Centro Cultural que poderá abrigar uma creche e um asilo". P46f indica, com cuidado, algo na mesma direção: "Acho que nosso futuro aqui em São Paulo é abrir, eu não vou chamar asilo, mas um hotelzinho quatro estrelas, porque nós temos várias [...]". Preocupada em 
precisar que não são os filhos que estão "descartando" os pais, P46f complementa:

[...] não por parte dos filhos, por parte deles (dos pais). Eles não gostam de ser peso, tanto para o filho como para qualquer um da família. Então, eu conheço muitas pessoas que têm a casa, convivem e tudo mais, mas estão sós, por quê? Porque não gostam de morar com o filho, com quem quer que seja da família, querem a privacidade deles, não querem ser peso morto [...]. A gente percebe que é uma coisa mais dolorida, né? Mas eu acho que esse é o nosso futuro, logo, logo (P46f).

\section{Separações}

Mesmo que caiba à mulher, como vimos, educar os filhos, o homem é o responsável, em última instância, por eles. Isso fica claro no processo de separação previsto no islamismo. No islamismo, a separação é autorizada, mas "de tudo o que é autorizado é o pior", disse-me um entrevistado. Os casos são raros por várias razões: a família é tida como um valor essencial, a mulher sujeita-se ao marido para permanecer junto aos filhos, em muitos casos, a separação apenas não é oficializada, porque a sociedade vê com maus olhos. "Quando há problemas entre marido e mulher e o casal não vai bem, procura-se um mediador" (R20m). "Nas brigas de casal: traz parente dele e dela para conversar e acertar", afirma L60m, ele próprio casado com uma prima 17 anos mais moça. No entanto, após refletir um pouco na supremacia masculina, completa: "Eu não sei como uma pessoa briga com mulher". De qualquer modo, se o(s) mediador(es) não logram seu intento de unir o casal, a separação pode se consumar. Como ficam então os filhos?

Na separação, a mulher não é obrigada a criar filho dele: porque o filho é dele (Q28m). Se tiver filhos, a criação e a educação são do pai. Quando um casal se separa, os filhos vão morar até a idade de 7 anos, com a mãe. O pai é obrigado a sustentar, mesmo que estejam com a mãe, até os 7 anos. Depois dos 7 anos, passa para o pai, é obrigação dele, os filhos são dele. Para mim, é duro, porque eu sou nascida aqui, mas para a nossa cultura de lá, faz sentido. O pai que tá gerando, né? É o principal interessado nos filhos, realmente é o pai, e outra, ele (o pai) sempre se casa, sempre tem outra família, então, eles têm que se adaptar aos outros irmãos, são todos irmãos, são irmãos deles, enquanto a mãe, não. Porque o pai é diferente (P46f). 
Observe como a cultura patriarcal "naturaliza" os filhos como pertencentes ao pai, a ponto de a entrevistada afirmar que ele é que "está gerando"; e como é dado por certo que o homem vai se casar novamente (e ter outros filhos), ao contrário da mãe.

O que acontece com a mãe separada? “Quando há separação, a tendência é (a mulher) voltar para a casa dos pais. Porque, quando ela casa e vai para a casa do marido, a casa é do marido, então ela volta, se tiver algum acordo e ela tiver alguma residência, aí, sim, ela fica morando sozinha, mas, caso contrário, não, a tendência é voltar para a casa dos pais" (P46f). O traço patriarcal também se encontra presente no tema dos casamentos mistos. Todos os entrevistados manifestaram a preferência por casamentos endogâmicos, com os noivos pertencendo à mesma religião, embora muitos reconheçam que o número de casamentos mistos na comunidade muçulmana venha aumentando significativamente.

É mais fácil para o homem muçulmano casar-se com uma mulher não-muçulmana do que o contrário: "O filho pode; a filha, a religião não permite, pois quem manda é o marido e, se casa fora, muda a religião" (L60m). A interdição da mulher de casar fora do grupo religioso, ainda que não proibida pelo Alcorão, vem daí, pois a religião da família é a religião do pai. Assim, implícito está que, no casamento misto, a mulher é que deve se converter à religião do homem. Mesmo nesses casos em que o noivo é muçulmano e a noiva, não, a situação do casal, com o tempo, pode gerar tensões consideráveis, advindas das pressões da comunidade. Um ponto importante, implícito ao tema, diz respeito, é claro, à identidade religiosa dos filhos. O temor é que estes sejam criados longe da fé islâmica. A comunidade vê ainda com reservas os raros casos em que o homem, não-muçulmano, resolve se converter para se casar com uma muçulmana. De qualquer modo, é uma opção menos grave do que a mulher simplesmente casar fora do grupo, pois é comum, nesse caso, seu ostracismo perante a comunidade. Além disso, a situação é embaraçosa para os pais e irmãos, que têm de se justificar sobre o fracasso em educá-la de modo apropriado.

O casamento com noivos de outras religiões é tido assim como problemático: as complicações derivam do relacionamento difícil entre famílias, "fica difícil conciliar, surgem problemas na educação dos filhos. E mesmo na sociedade, os amigos muçulmanos ficam com um certo pé 
atrás [...] - preferiu uma de fora, será que não tinha nenhuma aqui que servisse?" (R20m).

N52m, preocupado com o casamento de seus filhos, explica:

Quando você tinha 20 anos, você não queria saber do seu pai e da sua mãe, nem casa onde nasceu teu pai nem onde ele morou. Quando você chega aos 40 anos, vai querer saber de onde ele é e, indiretamente, e sem você perceber, você acaba voltando às suas origens. Começa a valorizar as suas origens, começa a voltar pra elas. E aquela menina também vai acabar voltando pras suas origens. E na maioria das vezes vai dar choque, muitas vezes. Porque ambos começam a voltar pras origens e a distância começa a ficar maior entre eles.

P46f relata:

Quando esse meu irmão resolveu se casar, foi um drama na família. Foi um choque muito grande, meu pai não aceitou o casamento dele, ficou muitos anos sem falar com ele, com a minha irmã foi a mesma coisa, com a minha irmã, quase sai uma coisa pior, porque ele não se conformou, ficou um bom tempo realmente sem ter um relacionamento com eles. Mas hoje... depois que nascem os filhos... Aí, tudo muda, tudo vira filho, tudo vira normal. Eles estão em casa, almoçam, jantam nos finais de semana, não tem diferença nenhuma, mas, sim, foi um choque, no início, né? (P46f).

Essas e outras considerações deixam entrever que os casamentos mistos vêm aumentando. Tal tendência se mostra como quase inevitável, pois, por mais forte que seja a sociabilidade das famílias, interna à colônia, os filhos acabam circulando por ambientes fora da comunidade, sobretudo ao freqüentarem escolas. N52m explica por que, na sua opinião, não existem casamentos arranjados. Seus argumentos, contudo, são mais uma prova inequívoca da grande influência da família sobre as decisões matrimoniais:

Claro, porque sempre nas cidades pequenas há um tanto de casamentos quase arranjados, pelo tamanho da cidade, não por imposição da família. Pelo tamanho da cidade, as pessoas ficam mais perto, então acaba acontecendo esse casamento arranjado, mas não tem imposição. Não existe, a gente sempre ouviu falar que eles impõem [...]. Encontra um que a família ajeita e não aceitou, berrou e gritou, como tem aqui também, mas é um em cada 10 mil. Claro, você tem um filho, você mora numa cidade que tem 400 casas, 500 residências, então você conhece 
Sociabilidades e Valores: Um Olhar sobre a Família Árabe Muçulmana...

mais as residências (pessoas), mais que seus filhos, tem uma vivência maior, então sabe qual é a família mais decente, mais nobre. Então você prefere que seu filho case naquela família, e às vezes ele cai numa menina que você já sabe o passado dos pais dela, né, os tios, os avós, porque lá a relação dos avós, de descendência, é muito importante, em nosso costume é muito importante. Se tem uma família lá meio engripada, meio torta, pois é, a família acaba ficando rejeitada. Então, se os pais conhecem descendências mais do que os próprios filhos, eles acabam falando, olha, aquela lá é boa, aquela lá é não sei o quê. Acabam orientando, encaminhando dentro do possível. Mas, se ele vai bater o pé, aí não tem como, né?! Agora, quando se trata de uma aldeia pequena, então acaba se tornando quase obrigatório. Não é que nem aqui, país muito grande. Lá são cem casas, oitenta casas, duzentas casas. Normalmente se casa na aldeia. É difícil casar entre aldeias. Tem, mas é raro, tem aquela pessoa que tem ligação com outra cidade, acaba indo lá, acaba conhecendo alguém, mas o normal é mais nas aldeias, mas, é claro, existe casar em outro lugar, existe, mas em números reduzidos. Deve dar de $3 \%$ a $5 \%$, eu acho que não passa de $10 \%$ (N52m).

Preocupada com o futuro de seus sobrinhos adolescentes e com a percepção de que é mais fácil a um menino muçulmano relacionar-se com alguém de fora da colônia, P46f avalia que "os jovens, hoje, têm uma dificuldade imensa de se relacionar com meninos e meninas muçulmanos. A colônia é grande, mas eles têm dificuldade, por quê? Porque ainda nós temos algumas raízes, que a menina não pode namorar, que a menina não pode fazer isso, aquilo". Muitos jovens encaram tais restrições como muito severas, sobretudo as meninas, que reclamam da iniqüidade de tratamento em relação a seus irmãos. P46f percebe então que o sistema incentiva meninos muçulmanos a se relacionar com meninas não-muçulmanas, já que as regras para um namoro com alguém da colônia são por demais estritas.

No centro das preocupações, como já observado, está o resguardo da pureza feminina, no limite, a ameaça das relações sexuais pré-conjugais. Um hadice ${ }^{10}$ popular atribuído ao profeta Maomé, e freqüentemente citado, diz que "quando um homem e uma mulher sentam juntos sozinhos, o terceiro que os acompanha é Satã". Assim, o problema é o namoro à moda ocidental, sobretudo agora que a prática do ficar vem ganhando terreno. O namoro, compreendido como uma oportunidade para que um casal se conheça, pode ser visto como interessante desde que seja absolutamente tutelado, supervisionado. É nesse sentido que 
as atividades centradas nas sociedades beneficentes anexas às mesquitas podem mitigar as compulsões da juventude, oferecendo uma alternativa de socialização entre jovens vista como conveniente, sob os olhares zelosos dos pais.

Q28m, que atualmente é noivo de uma moça da colônia, explica que seu pai veio solteiro, mas já namorava antes sua mãe. "Foi o primeiro namoro dele, ela era meio prima. Se largasse, era feio pra ele e feio pra ela", sugerindo que só se pode desistir de um namoro por um motivo muito grave. Questionado sobre a influência do amor no casamento, Q28m expõe seu ponto de vista: "Amor, não tem isso de achar uma cara-metade. Tem que ser um processo, uma relação construída. Assim, não vai ter traição. Como já quer amor se não conhece a futura esposa? O amor vem depois". De fato, é provável que o amor, no sentido romântico e ocidental do termo, não faça parte, ao menos inicialmente, das expectativas de um casamento. Em parte essa circunstância é compensada, fora do casamento, pelos laços afetivos muito próximos com a família e, para as mulheres, com amigas do mesmo sexo, com as quais trocam confidências.

Na condição de noivo, Q28m explica como se dá o processo:

[...] a família é que se preocupa em casar o filho. Então ela faz propaganda para a outra família, a da moça. Ressalta seu caráter, dignidade, trabalho. Diz que tem intenção séria. Começa a convidar a família para vir jantar. A outra família retribui. Então aí os pretendentes trocam pequenos olhares, têm curiosidade [...]. Às vezes, o não vem dela, se ela não quer, mas, às vezes, vem com o estudo (análise) dos pais.

Longe estamos, portanto, de apreender o casamento "como uma via privilegiada de afirmação de uma vida independente, permitindo concretizar estratégias de vida desvinculadas da família de origem", conforme observou Oliveira (1985:114) ao analisar famílias de trabalhadores camponeses no interior paulista. Ao contrário, o conhecimento e a avaliação da família do cônjuge, de sua condição econômica e social, pela família, são pontos fundamentais na consideração dos casamentos. Sendo o casamento tão importante, cabe à família tomar a iniciativa para tratar de assunto tão crucial.

Em alguma medida, isso explica as proporções relativamente altas de casamentos entre primos de primeiro e segundo graus, historicamente observáveis, tanto na comunidade muçulmana quanto anteriormente 
na cristã. $\mathrm{O}$ fenômeno ocorre também na própria terra de origem, bem como em outros países que receberam imigrantes árabes. Já que, para casar, a família deve proceder a uma avaliação a respeito de como a outra educou o pretendente, eleger um cônjuge no interior da própria família representa, desse ponto de vista, alguma segurança. Há, portanto, no horizonte das famílias, conforme observaram Kaufman e Naim, analisando a trajetória de uma família muçulmana internacionalizada, sempre um estoque de "sobrinhas, sobrinhos, primas e primos, sobre os quais se trocam informações a respeito daqueles disponíveis" (1996:176, tradução do autor).

De modo geral, reconhece-se hoje a importância dos estudos, de uma educação formal, e os muçulmanos orgulham-se de terem abrigado historicamente grandes civilizações, em territórios sob seus domínios, exercendo inclusive tolerância religiosa em relação a minorias não-muçulmanas. O próprio profeta Maomé pregava ser uma obrigação para todo muçulmano e muçulmana procurar o conhecimento (Hayek, s.d.). Contudo, observa-se que a importância com que a educação formal é encarada pelas famílias que do Líbano vieram ao Brasil normalmente varia conforme o gênero da criança. P46f explica que "as mulheres sempre foram mais restringidas [...]. Não gostava muito que fosse à escola, aprender a ler e a escrever era o suficiente". Hoje, a comunidade organizou-se e mantém uma escola islâmica na Vila Carrão, zona leste de São Paulo, que atende crianças matriculadas desde o jardim de infância até o ensino médio. Essa, porém, é uma iniciativa relativamente recente e, obviamente, nem toda a comunidade tem seus filhos nessa escola. É provável também que muitas famílias prefiram matricular seus filhos em escolas privadas confessionais a matriculá-los em escolas públicas, buscando garantir certa qualidade de ensino. Q28m lembra que também estudou em escola católica, em um colégio de padres ao lado da paróquia de Santo Antônio do Pari, próximo à rua Oriente. Ele conta que suas sobrinhas, que usam véu, estudam hoje lá. "Tive que falar com o frei para matricular, mas eles não restringiram".

Refletindo sobre sua trajetória, P46f avalia as tensões a que foi submetida: "Acho que, como qualquer outra família, nós tivemos, assim, um problema, não um problema, mas um convívio de aprender a conviver entre a cultura brasileira e a nossa cultura, que é muito diferente. Então, existe uma rigidez, condutas - como é que eu vou chamar? - hábitos que, no dia-a-dia, fincam raízes. E você não descola delas". Ao longo de seu depoimento, é perceptível uma espécie de dupla jornada 
em sua educação: a da escola formal, exterior, não-muçulmana, importante para obter um diploma capaz de lhe assegurar algum futuro; e a de sua casa, interior, em que os valores mais tradicionais da comunidade eram instilados. São dois mundos em tensão e que de alguma forma tiveram de ser acomodados na trajetória da maioria das famílias. R20m freqüenta hoje tanto o curso de Administração na Universidade Paulista - Unip quanto a "universidade islâmica", onde tem aulas com o xeique. Preocupa-se com a possibilidade de perder suas raízes e, por causa disso, em 1995, esteve por quinze dias no Líbano.

L60m tem quatro filhos homens no Brasil, além de mais dois e uma caçula, de 8 anos, no Líbano. Em 1988, mudou-se para o Líbano para melhor educar seus filhos "na religião". P46f julga que a educação dos filhos muçulmanos hoje está se tornando cada vez mais difícil: "Hoje, a criança tem outras informações, tem outra visão, [...] pelo sistema, pelo ambiente que nós estamos vivendo, a televisão hoje informa as crianças, educa as crianças, de maneira que você não tinha há trinta, quarenta anos, hoje a criança tem o computador na frente dela, ela manuseia aquilo lá como se fosse um brinquedo". Mesmo assim, reconhece que muito se tem avançado, em termos de novas posturas, na comunidade: "A tendência é se abrir, esse leque já abriu e vai continuar abrindo. Eu vejo que, ao longo desses anos, esses últimos vinte anos, eu vejo que as famílias se adaptaram mais à cidade, aos costumes [...]. Houve uma mudança grande, tem muitas coisas, por exemplo, que a nossa religião não permite e que você vê hoje normalmente, entendeu? Houve uma adaptação". R20m, ele próprio um jovem universitário de 20 anos, preocupado em cultivar suas origens islâmicas, avalia que, hoje, o maior desafio para sua geração é o relacionamento sexual. “É uma verdadeira jihad ${ }^{11}$ interna, muito sacrifício. É muito mais fácil fazer o jejum no ramadã. Por causa disso", conclui, "muitos jovens têm tendência a casar mais cedo. Aí resolve, mas, por outro lado, perdem a juventude" (R20m). Em casos extremos, é provável também que os pais imigrantes incentivem um casamento precoce de seus filhos, quando defrontados com uma cultura que lhes é estranha. Eisenlohr cita o depoimento de uma jovem entrevistada, referindo-se ao casamento, aos 14 anos de idade, de sua irmã mais velha:

Quando meus pais vieram à América, conterrâneos árabes começaram a dizer: 'A presse o casamento de sua filha, porque ela vai se tornar americanizada. Ela vai começar a fumar', mostrando-lhes assim o lado ruim da cultura americana. Então meus pais acreditaram, porque não sabiam o que 
se passava na América. E enviaram-na de volta ao Líbano, casaram-na e trouxeram-na de volta. Ela não foi mais à escola, não se educou e tudo o mais, e tornou-se uma dona de casa com quatro filhos"' (1996:258, ênfases no original, tradução do autor).

De modo geral, pode-se assim concluir que um foco de preocupações constante para muitas famílias muçulmanas, no que diz respeito à educação de seus filhos, é o de como permitir e regular uma interação com a sociedade inclusiva, não-islâmica. Muitos avaliam e perseguem um tipo de integração capaz de preservar uma identidade islâmica para seus filhos, compreendida como a observância de crenças, práticas e valores na educação destes.

\section{Vivências Religiosas Distintas}

A própria vivência prática do islamismo, longe de se apresentar uniforme, encontra-se sujeita a muitas diferenciações. O reconhecimento desse subjetivismo como dimensão da religiosidade moderna é instituinte da própria sociologia da religião. Em trabalho recente sobre as articulações entre família, reprodução e ethos religioso, Duarte et alii (2006:45) apontaram a recorrente interação entre três vontades: a divina (decorrente da religião), a natural (decorrente das leis da natureza) e a humana, subjetiva. Os dados levantados nos permitem supor que as variações na vivência religiosa entre muçulmanos árabes em São Paulo normalmente ocorrem segundo diferentes categorias, associadas a cada indivíduo e sua família, tais como gênero, idade, nível escolar, origem social, trajetória de vida, tempo de chegada ao Brasil, densidade dos vínculos com a terra natal etc. Poderíamos ainda acrescentar, embora aqui não tenhamos espaço para explorar esse outro aspecto, a influência de diferentes líderes religiosos ${ }^{12}$.

Tais experiências de religiosidade diferenciadas respaldaram o surgimento do termo "Islã individualizado", entendido primariamente como um Islã vivido na esfera privada, um Islã onde o crente decide autonomamente quais elementos da religião considera ou não obrigatórios (Cesari, 1994):

O termo individualização usado no estudo da religiosidade muçulmana não é consensual, mas o argumento de Cesari segundo o qual haveria uma transformação do Islã no Ocidente e um declínio do papel das instituições religiosas tradicionais sobre as novas gerações dos muçulmanos converge com os resultados gerais de muitos outros estudos 
como os de Frégosi (2004), Khosrokhavar (1997), Martín Munõz et alii (2003) e Mohsen-Finan (2003), apontados por Peter (2005) em seu ensaio sobre a individualização do Islã na Europa (Castro, 2007:183).

A constatação da individualização da religiosidade muçulmana é quase uma unanimidade na pesquisa social européia, ainda que mudanças e intervenções internas, institucionais à tradição religiosa, obviamente possam ocorrer. Contudo, ressaltem-se a importância e o impacto do papel do indivíduo na negociação com a comunidade muçulmana mais ampla, quando sob influência de uma cultura ocidental e, especificamente, do meio social brasileiro (a rigor, paulistano). Tal perspectiva de análise se coaduna com a tendência já apontada por Luckmann (apud Casanova, 1994), ainda que de forma exagerada, de que a religiosidade tenderia a ser encontrada cada vez mais fora das instituições religiosas, em um processo denominado privatização da religião. Desde logo, porém, ressaltem-se o potencial conflito entre essa tendência de privatização da religião, por um lado, e a religiosidade muçulmana vivida na esfera pública, por outro ${ }^{13}$.

Tendo em vista tais considerações e os dados apresentados pela pesquisa, é fácil constatar que o islamismo, tal qual qualquer outra religião, suscita diferentes percepções no tocante à observância da religiosidade. O ponto de ajuste da distância entre a doutrina enunciada e a prática religiosa concreta vivida varia então segundo condições culturais e sociais. A identidade do grupo em questão, alicerçada fortemente sobre a religião, aliada à forte cultura patriarcal e patrilinear, gera constrangimentos decisivos na esfera do relacionamento dos indivíduos em família. Entre os casos aqui analisados, podemos mencionar as pressões familiares e da comunidade sobre os indivíduos para que: a) se casem jovens e constituam família prontamente; $b$ ) realizem casamentos endogâmicos, isto é, no seio da própria comunidade religiosa; c) gerem uma prole numerosa; d) assumam papéis diferenciados segundo o gênero, que normalmente implicam assimetrias no tocante a práticas, direitos e obrigações familiares (namoro fora do grupo, início das atividades sexuais fora do casamento, responsabilidade para com os pais etc). Além disso, as vivências religiosas associadas à religião muçulmana variam ainda segundo determinados atributos individuais: indivíduos com menos idade que freqüentaram escolas nãomuçulmanas, ou que apresentam maior tempo de permanência no Brasil (e poucos laços familiares com o país de origem), tendem a negociar e a tomar como menos absolutos os preceitos doutrinários religiosos e, 
conseqüentemente, a exercitar de modo diferenciado suas práticas, direitos e deveres familiares.

\section{ETNICIDADES EM TRANSIÇÃO}

Focalizando agora sob o prisma étnico, no Brasil, o conceito de etnicidade aplicado a processos migratórios veio substituir a antiga noção de assimilação, encarada como um continuum entre um passado de tradições herdadas e um futuro certo de integração ao novo país. No caso analisado, a cultura original é transformada e certos valores, ideologias e instituições de caráter étnico desaparecem ou são reelaborados; porém critérios de distintividade usados para marcar a identidade étnica persistem, apesar da influência do novo meio social. Etnicidade é então entendida como construção cultural historicamente determinada e iterativamente renegociada por solicitações tanto internas ao próprio grupo quanto externas da sociedade mais ampla (Seyferth, 1988:33, Truzzi, 1997:229).

Internamente ao grupo, já se exploraram aqui extensamente os conflitos intergeracionais e entre famílias diferenciadas segundo o tempo de chegada ao Brasil e a freqüência de contatos com a terra de origem. Restaria também acrescentar outro elemento de tensão, interno à comunidade, mesmo que não explorado nas entrevistas, representado pelos brasileiros não-árabes convertidos ao islamismo. Embora minoritários e, sobretudo, desprovidos de ascendência étnica que lhes facilite o acesso ao árabe (considerado língua sagrada para os muçulmanos), tais grupos também disputam, com maior ou menor intensidade, segundo cada mesquita, a definição da identidade muçulmana local. Assim, no campo religioso islâmico, os convertidos tendem a ser mais exigentes no cumprimento da doutrina, reafirmando a todo instante, conforme observou Castro (2007:226), "sua retidão e rigor na observância dos preceitos islâmicos, em contraste com os árabes, como forma de angariar maior capital dentro do campo, uma vez que o capital simbólico ligado à tradição de fundação da religião não lhes é, nem nunca será acessível".

Do ponto de vista externo, a conformação identitária do grupo é pautada pelas reações ao que alguns denominam processo de "demonização" do Islã, isto é, à imagem estereotipada que a sociedade e, especialmente a mídia, alimenta em relação ao grupo. Essa observação remete à preocupação dos líderes de zelarem (assim como cada família) pela 
imagem própria da comunidade junto à sociedade mais abrangente. É notória a preocupação em desfazer a imagem de extremismo vulgarmente associada aos muçulmanos, sobretudo após o 11 de Setembro ${ }^{14}$. $\mathrm{N} 52 \mathrm{~m}$ reclama do preconceito com que a grande imprensa trata o grupo: "Para ela, só existe terrorista muçulmano, nunca um terrorista é qualificado como cristão ou judeu. Nesses casos, ele é só terrorista. Por quê?". Ele duvida que Osama Bin Laden fosse capaz de planejar algo tão complexo como os atentados: "Você acredita que um cara barbudo, que anda de camelo pelo deserto, conseguiria organizar tanta coisa? É com certeza armação americana, e de Israel".

Outro ponto sensível, conforme já se observou nas entrevistas, diz respeito à afirmação de que os muçulmanos submetem, oprimem e exploram suas mulheres. O discurso dominante dos entrevistados é que a religião muçulmana, ao contrário, confere um papel de destaque às mulheres no ambiente familiar, ao valorizá-las por seu caráter e virtude, e não por sua beleza e juventude, protegendo-as assim muito mais que na cultura ocidental, na qual uma monogamia imposta e hipócrita apenas acoberta traições e exime os homens de suas responsabilidades no tocante a relacionamentos extraconjugais (Castro, 2007:216).

Conquanto tais preocupações em relação à imagem da comunidade se encontrem sempre presentes, o Brasil é visto como um país excepcionalmente acolhedor. A maioria julga ser o preconceito aqui mínimo, "o que existe é má informação". Ao final, avaliaram também como muito positivo o papel da novela O Clone, da Rede Globo, ainda que o seu desenrolar tenha sido motivo de tensões por parte da comunidade:

É lógico que a maior parte das coisas foram passadas na novela com autorização das sociedades beneficentes de São Paulo e do Rio de Janeiro [...].Houve algumas coisas sim, que reclamaram [...]. O caso da castração da mulher, não foi permitido, por quê? Porque isso não é da religião, isso é da cultura do país. Eles achavam que era da religião [...]. Então, houve algumas colocações que eram realmente importantes, não pode confundir coisa de hábitos culturais com a religião (P46f).

M57f, zelosa em resguardar a imagem da comunidade, complementa: “Houve má informação com relação aos muçulmanos. Fui ao Rio falar com a Glória Perez. Falei que estava sendo cobrada pela comunidade. Ela respondeu que na novela tinha que ter um pouco de pimenta... Mas, "em geral", concede, "a novela foi positiva para a imagem da comunidade". 
Assim, do mesmo modo que as famílias, pode-se afirmar que também as lideranças do grupo estão submetidas a tensões de mesmo caráter: como preservar a identidade étnico-religiosa e ao mesmo tempo quebrar distâncias, atenuar preconceitos e o particularismo nos costumes, aproximar, aparar arestas, enfim, apresentar a comunidade como integrada à sociedade brasileira? É possível construir uma escala de lideranças, entre pólos com maior ou menor disposição de negociar uma imagem favorável perante o restante da sociedade, em detrimento às vezes da afirmação de valores tradicionais.

Tendo em vista tais elementos, é nesse sentido que Charles Tilly (1990:92) se referirá à face de Janus do conceito de etnicidade, em constante negociação com sua capacidade de olhar ao mesmo tempo para as realidades cambiantes tanto internas ao grupo quanto externas da sociedade inclusiva.

\section{CONSIDERAÇÕES FINAIS}

Pode-se afirmar sem dúvida que há um conjunto significativo de características comuns, orientadoras das configurações familiares tanto de árabes de origem cristã quanto de árabes de origem muçulmana em São Paulo. Não obstante, crenças religiosas distintas, épocas de chegada também distintas, bem como a maior proximidade religiosa das famílias de origem cristã com o catolicismo dominante no Brasil, acabaram condicionando um conjunto de especificidades. O que é possível concluir a respeito de valores e sociabilidades entre muçulmanos em São Paulo?

Em primeiro lugar, é evidente, a exemplo dos descendentes de árabes de origem cristã, a centralidade da família. Ela fornece a referência básica para indivíduos, dificilmente reconhecíveis isoladamente enquanto tais, isto é, fora de uma família. A família é o elo estruturante tanto da vida econômica - já que os negócios são maciçamente familiares - quanto da vida social da comunidade, pois as práticas religiosas e as correspondentes atividades exercidas no âmbito das sociedades beneficentes, anexas às mesquitas, se alicerçam essencialmente sobre a participação e o engajamento das famílias. É provável que as redes familiares também atuem no sentido de proteger os indivíduos de trajetórias acentuadas de descenso social.

Acredita-se ainda que "a paz e a segurança proporcionadas por uma unidade familiar estável [são] essenciais para o desenvolvimento espi- 
ritual de seus membros" (Hayek, s.d.). Conforme reiterado em inúmeros trabalhos antropológicos sobre comunidades muçulmanas em diversos países do mundo árabe, o casamento e a geração de filhos constituem condições essenciais ao próprio reconhecimento social dos indivíduos na comunidade, ao mesmo tempo em que a própria realização, tanto da feminilidade quanto da masculinidade, pressupõe o casamento (Altorki, 1986; Delaney, 1991; Wikan, 1982).

Graças ao particularismo religioso de um grupo imerso em uma sociedade preponderantemente cristã e também à existência de contingentes imigrados em épocas relativamente recentes, circunstância que adensa os vínculos sociais, econômicos e religiosos com a terra de origem, desenvolveu-se em São Paulo uma sociabilidade própria e endógena ao grupo, marcada pela negociação permanente de fronteiras entre o secular e o sagrado. Nesse sentido, o islamismo pretende, e em alguma medida logra, entre seus praticantes, ser não apenas uma religião mas um "sistema completo de vida" (Hayek, s.d.).

Inevitável é que, dessa negociação permanente, surjam tensões. Talvez mais agudas para os jovens e para a primeira geração nascida no Brasil, esgarçada entre o passado e o futuro, tendo que desempenhar papéis pouco conciliáveis nas esferas do privado e do público. Nesse contexto, os casamentos mistos, ainda que cada vez mais freqüentes, são encarados como uma ameaça à sobrevivência da comunidade (sobretudo quando o homem não é muçulmano) ou, no mínimo, como geradores de turbulências desnecessárias e que devem ser, sempre que possível, evitadas, pois é no momento do casamento que os pais demandam um compromisso tangível com as tradições étnico-religiosas.

É evidente também, como se procurou aqui demonstrar, o caráter fortemente patriarcal e patrilinear dos valores presentes nas famílias muçulmanas, expresso em múltiplas manifestações: os papéis distintos atribuídos ao homem e à mulher (em duas palavras, prover e procriar), a preferência por filhos homens, a instituição do dote, os privilégios masculinos de herança, as práticas associadas ao resguardo feminino etc. Isso não significa menosprezar o papel muito ativo das mulheres na organização do cotidiano familiar, na tessitura de relações de vizinhança e entre famílias de mesmo credo, relações estas sempre vincadas segundo a perspectiva de gênero. Incumbidas de acompanhar mais de perto a educação dos filhos desde a primeira infância, é provável também que elas se mostrem mais sensíveis a acolher e a adminis- 
trar tensões geracionais, funcionando como intermediárias entre a autoridade paterna e as demandas filiais.

Por outro lado, tendo agora por contraste a comunidade de origem árabe cristã, de modo geral mais aculturada à sociedade brasileira, é possível discernir a maior importância da vivência religiosa - e tudo o que ela significa em termos sociais - para o grupo muçulmano. Pode-se afirmar, a esse respeito, que no grupo muçulmano a identidade religiosa prevalece sobre a identidade étnica, ao contrário do que parece ocorrer entre árabes cristãos. De fato, caso a identidade étnica fosse preponderante para ambos os grupos, o número de casamentos entre árabes cristãos e árabes muçulmanos supostamente seria muito maior. Entretanto, o que se observa é que são muito raros, de modo que as duas comunidades podem ser compreendidas como dois grupos relativamente distintos, que pouco se misturam. Há interesses comerciais que se concatenam, há um coincidente antagonismo em relação à política sionista, há muitos traços culturais em comum, mas que não se traduzem em ligações familiares, graças ao distanciamento imposto por tradições religiosas distintas e pela herança amarga de conflitos históricos na terra de origem.

É difícil prever o futuro da comunidade muçulmana em São Paulo, além da certeza de muitas tensões a serem enfrentadas pelo grupo. De um lado, a recente (re)destruição do Líbano por Israel tende a incrementar o fluxo de novas famílias imigrantes ao Brasil, assim como ocorreu quando da guerra civil libanesa a partir de 1975. Sabemos que as migrações ocorrem, em grande medida, apoiadas por redes de conterrâneos, e o Brasil (São Paulo em particular) já abriga uma comunidade expressiva, com vínculos recentes, capaz de abrigar e acolher novas famílias. Os já estabelecidos, muitos deles parentes e conterrâneos dos novos imigrantes, fornecem aos primeiros não apenas apoio psicológico mas também social e econômico, sob a forma de empréstimos, empregos e moradia, facilitando a inserção dos recém-chegados. O aumento do fluxo de imigrantes ao Brasil deve ocorrer, sobretudo quando se tem em vista o recrudescimento da política migratória norte-americana em relação a árabes após o 11 de Setembro, já que os Estados Unidos sempre representaram uma opção de destino importante no cenário internacional. Avolumando-se a imigração de muçulmanos a São Paulo ${ }^{15}$, a comunidade tende a robustecer-se numérica, social, econômica e culturalmente. 
Por outro lado, a tais fluxos se opõem as preocupações das famílias recém-imigradas em criar seus filhos em um país não-muçulmano, mais sujeito ao que um dos entrevistados designou como "lassidão moral do Ocidente". Essa tensão permanente entre o ficar e o voltar regulou, até o recente conflito bélico, o movimento de idas e vindas constantes de famílias do grupo à terra de origem. São notórias as dificuldades de preservação do grupo, quando se pensa nas gerações mais recentes, nascidas no Brasil. A sociedade brasileira, vista pelas lideranças (e em boa medida também pelas famílias) como demasiadamente permissiva, tende a solapar, junto aos mais jovens, os valores próprios, caros ao grupo, provocando inevitáveis tensões intergeracionais. Elas se expressam de inúmeras formas, desde as dificuldades de se preservar o uso do árabe no cotidiano familiar, até complicações crescentes associadas à observância de preceitos da chari'a, como vestimentas adequadas, jejum, interdição alimentar e do álcool. Da mesma forma, a presença cada vez maior da mulher no trabalho, a escolarização crescente dos filhos freqüentando escolas lado a lado com não-muçulmanos, a crescente erotização da sociedade e a conseqüente ocorrência de relações pré-conjugais, a maior ocorrência de casamentos mistos, a ruptura do isolamento propiciada pela TV e pela internet, a adesão a valores mais individualistas e menos solidários, tudo isso é encarado como pernicioso, imoral e destrutivo, contribuindo para minar a cultura original do grupo e exigindo necessariamente adaptações e maleabilidades nem sempre disponíveis à primeira mão. O desafio é como construir uma solução, no interior das famílias e da comunidade, que permita manter sua identidade étnico-religiosa, selecionando, ao mesmo tempo, entre os direitos e deveres associados ao papel de cada indivíduo, condutas e comportamentos capazes de apontar um futuro para os mais jovens e um convívio enriquecedor com a sociedade mais ampla.

Muitas contradições tendem assim a aflorar e a exigir negociações tanto de caráter intergeracional (pois é evidente que os valores patriarcais rígidos serão cada vez mais questionados pelas novas gerações) quanto entre levas de imigrantes mais antigas, já adaptadas ao Brasil, e levas mais recentes, que trazem consigo uma cultura mais ortodoxa. Por causa da imigração mais próxima, clivagens entre aculturados e recém-chegados fazem muitas vezes mais sentido do que entre diferentes estratos sociais no interior da comunidade ${ }^{16}$.

De um ponto de vista sociológico, mais do que afirmações conclusivas, o importante é reconhecer que os traços culturais do grupo estão sujei- 
tos a mudanças, adaptações e releituras, fruto da interação do grupo com a sociedade mais ampla, provocadora de reinterpretações das próprias tradições étnico-religiosas. Assim, etnicidade e religiosidade tendem a reconfigurar-se continuamente à medida que o grupo cresce (inclusive com convertidos) e se reproduz na sociedade paulista, reage aos estereótipos que lhe são imputados e interage com essa mesma sociedade de modo mais denso, através das novas gerações nascidas em São Paulo, transformando assim sua própria identidade. De qualquer modo, diferentes parcelas da comunidade deverão conviver, não sem conflitos, em esferas religiosas, sociais e econômicas comuns, abrindo margem para compromissos variados entre a tradição e a contemporaneidade.

(Recebido para publicação em agosto de 2007)

(Versão definitiva em janeiro de 2008)

\section{NOTAS}

1. Nesse país, estima-se que os muçulmanos perfaçam um contingente de 5 milhões de indivíduos, enquanto a população muçulmana do planeta é avaliada em mais de 1 bilhão de fiéis, $18 \%$ dos quais habitando o mundo árabe. A Indonésia é o país que abriga o maior contingente.

2. Mary Sengstock (1996:293, tradução do autor) reporta uma situação semelhante: “Essa comunidade apresenta uma característica extremamente social. Todos se preocupam com as atividades do outro e esperam ser envolvidos nelas. Mesmo realizar entrevistas com fins de pesquisa na comunidade raramente se constitui como uma atividade individual. Visitas são quase constantes, de modo que o entrevistador quase nunca surpreende o entrevistado sozinho. Nos poucos momentos em que se encontra só, este raramente permanece nessa condição. Os vizinhos notam a presença de alguém novo e aparecem para ver o que está acontecendo". Na maioria dos casos, reporta ainda essa autora, os intrusos acabam também participando da entrevista.

3. A palavra zakat significa tanto purificação quanto crescimento. Segundo Hayek (s.d.): “Nossas posses são purificadas com a separação de uma parte delas para os necessitados e, a exemplo da poda das plantas, o corte equilibra e estimula novos crescimentos. Cada muçulmano calcula individualmente o seu próprio zakat. Na maioria dos casos, isso envolve o pagamento de dois e meio por cento do capital da pessoa".

4. Declaração de fé que afirma não haver outra divindade além de Deus e ser Maomé seu mensageiro. 


\section{Oswaldo Truzzi}

5. Refere-se às orações obrigatórias (em árabe, contendo versículos do Alcorão), praticadas cinco vezes ao dia (na alvorada, ao meio-dia, no meio da tarde, no crepúsculo e à noite) pelos muçulmanos. Apesar da preferência por praticá-las coletivamente, em uma mesquita, o fiel pode orar em qualquer lugar.

6. “Além de o jejum ser muito benéfico para a saúde, é considerado um método de purificação pessoal. Ao privar-se dos confortos mundanos, mesmo por um período curto, o jejuador adquire verdadeira simpatia por aqueles que sofrem fome e ao mesmo tempo desenvolve a sua vida espiritual" (Hayek, s.d.).

7. Devem, por exemplo, antes das orações (salat), lavar a face, os braços e pernas até a altura dos joelhos.

8. A doutrina islâmica condena a ingestão de álcool ou de "qualquer espécie de inebriantes que causem dependência", bem como de carne de porco e de produtos feitos com sangue. As carnes devem ser preparadas segundo método específico capaz de eliminá-lo. “O Profeta Maomé ensinou que 'seu corpo tem direito sobre você', e o consumo de comidas saudáveis e o levar um estilo de vida saudável são vistos como obrigações religiosas" (Hayek, s.d.).

9. Kulwicki (1996:191) constata, por exemplo, haver resistências entre homens da comunidade em aceitar assistência social pública nos Estados Unidos, porque esta é percebida como um traço negativo à condição de provedores econômicos.

10. Narração fidedigna do que o profeta Maomé disse, fez ou aprovou.

11. O termo jihad significa, literalmente, esforço e é utilizado normalmente em dois sentidos distintos: o de guerra santa, mais explorado pela imprensa quando se refere aos conflitos no Oriente Médio, e o de uma luta interior que cada um trava contra os desejos egoísticos para conseguir a paz interior.

12. Líderes mais ou menos conservadores influenciam as práticas religiosas efetivamente seguidas e, por decorrência, interferem na percepção de práticas, direitos e obrigações familiares dos fiéis. No Brasil, comunidades sunitas apresentam vínculos maiores com a Arábia Saudita, enquanto comunidades xiitas se relacionam primordialmente com o Irã. Tais vínculos podem significar tanto a importação de lideranças religiosas financiadas por esses países quanto a própria formação de lideranças brasileiras nesses países (Castro, 2007:218).

13. É nesse sentido, por exemplo, que o uso público do véu pelas mulheres muçulmanas incomoda os não-muçulmanos (consultar Castro, 2007:229).

14. Tal preocupação se mostra transparente, por exemplo, na brochura que apresenta o Islã e os muçulmanos a interessados (vide Hayek, s.d.).

15. Ainda é significativa a presença de muçulmanos em algumas regiões do sul do Brasil, como em Foz do Iguaçu, no Paraná, na área da chamada Tríplice Fronteira. Nessa região, observa-se uma presença significativa de xiitas, originários do sul do Líbano, motivada também pela fuga de conflitos na terra natal.

16. Certamente fazem muito mais sentido no caso de árabes muçulmanos do que entre árabes cristãos. 


\section{REFERÊNCIAS BIBLIOGRÁFICAS}

ALTORKI, Soraya. (1986), Women in Saudi Arabia: Ideology and Behavior among the Elite. New York, Columbia University Press.

ARDAILLON, Danielle. (1997), O Salário da Liberdade: Profissão, Maternidade, Negociações para uma Igualdade na Diferença. São Paulo, Annablume.

BOWEN, Donna L. e EARLY, Evelyn A. (1993), Everyday Life in the Muslim Middle East. Bloomington, Indiana University Press.

CANDIDO, Antonio. (1951), “The Brazilian Family”, in T. L. Smith e A. Marchant (eds.), Brazil, Portrait of Half a Continent. New York, Dryden Press, pp. 291-312.

CASANOVA, José. (1994), Public Religions in the Modern World. Chicago, The University of Chicago Press.

CASTRO, Cristina Maria de. (2007), A Construção de Identidades Muçulmanas no Brasil: Um Estudo das Comunidades Sunitas da Cidade de Campinas e do Bairro Paulistano do Brás. Tese de doutorado, UFSCar, São Carlos.

CESARI, Jocelyne. (1994), Être Musulman en France: Associations, Militants et Mosquées. Paris, Karthala.

CORRÊA, Mariza. (1994), "Repensando a Família Patriarcal Brasileira”, in A. A. Arantes et alii (orgs.), Colcha de Retalhos: Estudos sobre a Família no Brasil. Campinas, Editora da Unicamp.

DAHL, Tove S. (1997), The Muslim Family: A Study of Women's Rights in Islam. Oslo, Scandinavian University Press.

DELANEY, Carol. (1991), The Seed and the Soil: Gender and Cosmology in Turkish Village Society. Berkeley, University of California Press.

DONNAN, Hastings. (1988), Marriage among Muslims: Preference and Choice in Northern Pakistan. Delhi, Hindustan Publishing.

DUARTE, Luiz Fernando Dias. (2006), “À Guisa de Introdução: O Que Perguntamos à Família e à Religião”, in L. F. D. Duarte et alii (orgs.), Família e Religião. Rio de Janeiro, Contra Capa, pp. 7-13.

et alii (orgs.). (2006), Família e Religião. Rio de Janeiro, Contra Capa.

DURHAM, Eunice R. (1983), "Família e Reprodução Humana”, in B. Franchetto et alii (orgs.), Perspectivas Antropológicas da Mulher. Rio de Janeiro, Zahar, vol. 3 pp. 13-34.

EISENLOHR, Charlene Joyce. (1996), “Adolescent Arab Girls in an American High Scho$\mathrm{ol}^{\prime \prime}$, in B. C. Aswad e B. Bilgé (eds.), Family E Gender among American Muslims. Issues Facing Middle Eastern Immigrants and Their Descendants. Philadelphia, Temple University Press, pp. 250-270.

ELKHOLY, Abdo A. (1966), The Arab Moslems in the United States: Religion and Assimilation. New Haven, College and University Press.

FIGUEIRA, Sérvulo Augusto (org.). (1987), Uma Nova Família? O Moderno e o Arcaico na Família de Classe Média Brasileira. Rio de Janeiro, Zahar. 


\section{Oswaldo Truzzi}

FONSECA, Claudia. (1989), “A História Social no Estudo da Família: Uma Excursão Interdisciplinar". BIB, no 27, pp. 51-73.

FRÉGOSI, Franck. (2004), “L'Imam, le Conférencier et le Jurisconsulte: Retour sur Trois Figures Contemporaines du Champ Religieux Islamique en France". Archives de Sciences Sociales de Religions, no 125, pp. 131-146.

FREYRE, Gilberto. (1933), Casa-Grande e Senzala: Formação da Família Brasileira sob o Regime de Economia Patriarcal. Rio de Janeiro, Maia e Schmidt.

FUKUI, Lia. (1980), “Estudos e Pesquisas sobre Família no Brasil”. BIB, no 10, pp. 13-23.

GATTAZ, André Castanheira. (2001), História Oral da Imigração Libanesa para o Brasil: 1880-2000. Tese de doutorado, FFLCH/USP, São Paulo.

GREGORI, Maria Filomena. (2006), Famílias e Etnicidade: Arranjos e Interfaces. Trabalho apresentado no seminário Arranjos Familiares e Etnicidade, Centro de Estudos da Metrópole/Cebrap, São Paulo, agosto.

HADDAD, Yvonne Y. e SMITH, Jane I. (1996), "Islamic Values among American Muslims", in B. C. Aswad e B. Bilgé (eds.), Family E Gender among American Muslims. Issues Facing Middle Eastern Immigrants and Their Descendants. Philadelphia, Temple University Press, pp. 19-40.

HAJJAR, Claude F. (1985), Imigração Árabe: 100 Anos de Reflexão. São Paulo, Ícone.

HAYEK, Samir El. (s.d.), Compreenda o Islam e os Muçulmanos. São Paulo, s/ed.

HEILBORN, Maria Luiza. (2004), Dois é Par: Gênero e Identidade Sexual em Contexto Igualitário. Rio de Janeiro, Garamond.

KAUFMAN, Gladis e NAIM, Shamim. (1996), "An International Family: A Case Study from South Asia", in B. C. Aswad e B. Bilgé (eds.), Family E Gender among American Muslims. Issues Facing Middle Eastern Immigrants and Their Descendants. Philadelphia, Temple University Press, pp. 173-184.

KHOSROKHAVAR, Farhad. (1997), L'Islam des Jeunes. Paris, Flammarion.

KULWICKI, Anahid. (1996), "Health Issues among Arab Muslim Families”, in B. C. Aswad e B. Bilgé (eds.), Family E Gender among American Muslims. Issues Facing Middle Eastern Immigrants and Their Descendants. Philadelphia, Temple University Press, pp. 187-207.

MARTÍN MUÑOZ, Gema et alii. (2003), Marroquíes en España. Estudio sobre su Integración. Madrid, Fundación Repsol YPF.

MERNISSI, Fatima. (1975), Beyond the Veil: Male-Female Dynamics in a Modern Muslim Society. Cambridge, Schenkman Publishing Company.

MOHSEN-FINAN, Khadija. (2003), “La Mise en Avant d'une Citoyenneté Croyante: Le Cas de Tariq Ramadan”, in R. Leveau, K. Mohsen-Finan e C. W. de Wenden (eds.), De la Citoyenneté Locale. Paris, Institut Français des Relations Internationales.

OLIVEIRA, Maria Coleta F. A. (1985), “O Casamento e as Estratégias de Sobrevivência da Família Operária na Agricultura Paulista". Revista Brasileira de Estudos da População, vol. 2, no 1, pp. 105-143.

OSMAN, Samira Adel. (1998), Caminhos da Imigração Árabe em São Paulo: História Oral de Vida Familiar. Dissertação de mestrado, FFLCH/USP, São Paulo. 
Sociabilidades e Valores: Um Olhar sobre a Família Árabe Muçulmana...

(2006), Entre o Líbano e o Brasil: Dinâmica Migratória e História Oral de Vida. Tese de doutorado, FFLCH/USP, São Paulo.

PEIXOTO, Clarice E., SINGLY, François de e CICHELLI, Vincenzo (orgs.). (2000), Família e Individualização. Rio de Janeiro, Editora FGV.

PETER, Frank. (2005), Individualization and Religious Authority in Western European Islam. A Review Essay. Trabalho apresentado no workshop Muslim Religious Authorities in Western Europe, realizado pelo ISIM, Leiden, 30 de setembro-1ㅇde outubro.

SAFADI, Dalal Khalil e BASHA, Victoria Safadi. (1954), A Thousand and One Arabic Proverbs. Beirut, American Press.

SARTI, Cinthia A. (1996), A Família como Espelho: Um Estudo sobre a Moral dos Pobres. São Paulo, Autores Associados.

SCHILLER, Nina Glick et alii. (1995), "From Immigrant to Transmigrant: Theorizing Transnational Migration". Anthropological Quarterly, vol. 68, no 1, pp. 48-63.

SENGSTOCK, Mary C. (1996), "Care of Elderly Within Muslim Families", in B. C. Aswad e B. Bilgé (eds.), Family \& Gender among American Muslims. Issues Facing Middle Eastern Immigrants and Their Descendants. Philadelphia, Temple University Press, pp. 271-297.

SEYFERTH, Giralda. (1988), “Imigração e Colonização Alemã no Brasil: Uma Revisão da Bibliografia". BIB, no 25, pp. 3-55.

TILLY, Charles. (1990), "Transplanted Networks", in V. Yans-McLaughlin, Immigration Reconsidered. History, Sociology and Politics. New York/Oxford, Oxford University Press.

TRUZZI, Oswaldo M. S. (1992), De Mascates a Doutores: Sírios e Libaneses em São Paulo. São Paulo, Sumaré.

(1997), Patrícios: Sírios e Libaneses em São Paulo. São Paulo, Hucitec.

WIKAN, Unni. (1982), Behind the Veil in Arabia: Women in Oman. Baltimore, Johns Hopkins University Press. 


\begin{abstract}
Sociability and Values: A Perspective on Muslim Arab Families in São Paulo
\end{abstract}

This study explores the sociability and family values of Muslim Arabs in São Paulo, Brazil, based primarily on 10 interviews with individuals of different age groups, socioeconomic strata, and genders. With Christian Arab families as the counterpoint, the article contextualizes the arrival of these immigrants and discusses and investigates the family dilemmas and practices permeated by a strong patriarchal trait and the challenges faced by this religious minority. The article concludes that the group's ethnicity and religiosity tend to be continuously reshaped as the group grows and reproduces in local society, reacts to the stereotypes attributed to it, and interacts more intensely with this same society through the new generations born in São Paulo.

Key words: Muslims; Arab culture; patriarchal family; immigration

\title{
RÉSUMÉ
}

Sociabilités et Valeurs: Un Regard sur la Famille Arabe Musulmane à São Paulo

Dans cet article, on examine les sociabilités et les valeurs familiales de musulmans d'origine arabe à São Paulo, à partir de 10 entretiens auprès d'individus d'âge, statut socio-économique et sexe différents. Prenant en contrepoint des familles chrétiennes d'origine arabe, on cherche à situer l'arrivée de ces immigrés, à discuter leurs dilemmes et pratiques familiales très marquées par le caractère patriarcal, ainsi que les défis vécus par cette minorité religieuse. On conclut que le sens d'ethnie et de religiosité du groupe tend à se redéfinir sans cesse au fur et à mesure que le groupe grandit et se reproduit dans la société de la ville de São Paulo, qu'il réagit aux stéréotypes qui lui sont attribués et qu'il entre en interaction plus intense avec cette même société par l'intermédiaire des nouvelles générations qui y naissent.

Mots-clé: musulmans; culture arabe; famille patriarcale; immigration 